\title{
Political Party Financing and Corruption in Nigeria’s Fourth Republic: The Case of 2015 General Elections
}

\author{
Babayo Sule ${ }^{1 *}$, Mohammed Azizuddin², Mohammed Sani² and Bakri Mat ${ }^{2}$ \\ ${ }^{1}$ Department of Political Science, Faculty of Humanities Management and Social Sciences, Malaysia \\ ${ }^{2}$ School of International Studies, College of Law, Government and International Studies, Malaysia
}

\begin{abstract}
Political party financing is the process of funding the parties and the candidates that contested under their platform. However, in most developing democracies, elections and political party financing are marred with heavy allegations of corruption. The objective that this paper examined was the process of political party financing and how it's influenced or affected by corruption taking the 2015 General Elections as the case study in Nigeria's Fourth Republic. The methodology adopted for this work is the use of qualitative method of data collection and analysis. Data were obtained from primary sources using field work. The data obtained was analysed and discussed. The research discovered that, there was massive corruption in the 2015 General Elections unprecedented in the history of the country running in trillions of Naira (billions of Dollars). The research recommends that political party financing be monitored and strict regulations should be introduced to punish the offenders.
\end{abstract}

Keywords: Corruption; Election; Financing; Fourth republic; Nigeria and political parties

\section{Introduction}

The 2015 General Elections in Nigeria is a watershed in the history of democracy and democratization in the country and Africa at large. This is because it was the first time that the opposition unseat the ruling government and besides, the election was adjudged the most credible in the Fourth Republic at local, Africa and international level Elections in Nigeria are normally bedeviled with malpractices such as violence, rigging, vote buying, corruption and ethno-religious politics leading to crisis of legitimacy [1]. The 2015 General Elections was conducted in the atmosphere of tension and crisis of insecurity but it was for the first time dominated by issues such as Boko Haram insurgency, corruption, poverty, unemployment, merger of major opposition parties, use of smart card readers for voting etc. instead of the usual ethnic, regional and religious sentiments. This according to many scholars Ayanda et al. [2-4] made significant impact on the outcome of the elections and made it more credible than before. Political party financing has become an important issue in modern democracies in the quest ensuring transparency and discouraging corrupt practices in the contest for public elective office globally. This is because there are many cases in recent times worldwide of corruption scandals in the political party financing process. There is a global effort in curbing of excessive campaign spending through regulating of donation, maximum spending limit and increase public spending OECD. The major sources of political party financing are identified as contributions, private funding, personal sources and abuse of state resources [5]. Political party financing is very essential in democracy and it is expected that, it the process should be transparent and in line with the regulations provided by laws of a given country. Failure to adhere to the rules leads to corruption and other illegal practices. In Nigeria, there are set limits for elective offices of maximum campaign spending according to 2010 Electoral Act. All contestants are required to mandatorily adhere to the rules strictly [6]. Unfortunately, in Nigeria, politicians used the process of political party financing to enrich themselves while the electorates also get influence in the process through cliental-patron relationship where national resources are shared according to who access power or have access to those in power. Public funds are looted in order to finance political campaign in which in return the winners loot directly from the public treasury to accumulate wealth and harbor influence on their patrons [7-9]. The correlation between money and politics in Nigeria has impacted in corrupting the electoral process since violation of electoral rules through excessive spending gives some contestants undue advantage over others Nkechi [10]. This paper examined the process of political party financing in the 2015 General Elections and how the entire process was affected by corruption and other illegal activities which immensely affected the outcome of the elections.

\section{Objectives of the Study}

The main aim of this work is to examine analytically the entire process of political party financing in the 2015 General Elections and how the process was affected by corruption.

Other specific objectives that the work seeks to analyse include:

1. To examine the rules and regulations on political party financing in Nigeria's Fourth Republic;

2. To evaluate whether the maximum financial limit set has been adhered to by political parties and contestants and

3. To explore the impact of corruption on the process of financing the 2015 General Elections and how it affect the outcome of the election.

\section{Methodology}

The methodology for this work is qualitative method of data collection and analysis. The qualitative method is the use of both primary and secondary sources to obtain data from informants. It

*Corresponding author: Babayo Sule, Department of Political Science, Faculty of Humanities Management and Social Sciences, Universiti Utara, Malaysia, Tel: +60 4-928 4000; E-mail: babayosule@gmail.com

Received September 14, 2017; Accepted September 18, 2017; Published September 22, 2017

Citation: Sule B, Azizuddin M, Sani M, Mat B (2017) Political Party Financing and Corruption in Nigeria's Fourth Republic: The Case of 2015 General Elections. Arts Social Sci J 8: 298. doi: 10.4172/2151-6200.1000298

Copyright: (c) 2017 Sule B, et al. This is an open-access article distributed under the terms of the Creative Commons Attribution License, which permits unrestricted use, distribution, and reproduction in any medium, provided the original author and source are credited. 
also involves data analysis and a paradigm for research conduct in social sciences. The method in qualitative data involves the application of qualitative strategies within a qualitative paradigm and not only techniques [11]. Qualitative method of data collection consists of phenomenology, grounded theory, ethnography, narrative and case study. This study is a case study type as it attempted at examining the case of 2015 General Elections in Nigeria. The research used interview in generation of information using an unstructured interview and Focus Group Discussion (FGD). Informants were selected from organisations and agencies that are directly related with the conduct of elections in Nigeria and the fight against corruption. These organisations include the electoral body; Politicians, party stakeholders, Independent National Electoral Commission (INEC), Economic and Financial Crimes Commission (EFCC), academicians and Focus Group Discussion from some members of civil societies in Abuja Nigeria. From the above informants, six (6) were selected from politicians, four (4) from party stakeholders, three (3) from INEC staff, four (4) from EFCC officials, three (3) from academicians and eight (8) from the Focus Group Discussion. This makes a total of 28 informants and this has been proposed by Creswell (2014) as one of the average required number for qualitative data method in research. The informants were selected from among the senior officials for instance, politicians were selected from the two major parties; All Progressive Congress (APC) and Peoples Democratic Republic (PDP) and they are from the top elective political office holders. The party stakeholders were selected from the National Executives of the four major political parties that contested for General Elections in 2015, senior officials of high rank were selected at national level from INEC and EFCC while from the academicians, experience professors in the field of Political Science with specialization in elections, political party financing and corruption were chosen. From the FDG group, experience and competent individuals were selected in Abuja who were identified and interviewed in Unity Fountain where civil societies and other pressure groups used to meet for deliberations. The data obtained from the field is presented in statistical tools such as tables and charts taking simple percentage and analysed with the existing literature to arrive at research findings and discussions of findings.

\section{Theoretical Framework}

The work used two major theories which are integrated purposely for this research. They are:

\section{The rational choice theory of election and Clientalism}

The two theories are adopted to explain the existing literature and to give a new direction and discoveries in this field of knowledge. The Rational Choice Theory explains voters' behaviour and how it influences the choice of their candidates. The Clientalism explains the process of political party financing in a way that corrupt practices assume a special position of spending or seeking for political office for personal benefit and enrichment through collaboration with some allies who give their support either in cash, kind or mobilisation. Rational Choice Theory of election was derived from Economics theory of consumer rationality where buyers utilize their money for commodities that give them maximum satisfaction in purchasing them. So also, electorates are believed by Anthony Downs [12] and Kenneth Arrow [13] to have identified economic indicators such as resource allocation and provision of goods and services as determinants of choice of a political leader. Voters choose those leaders that they think can provide them with maximum provision of services and welfare in return for offering their votes. It is a decision or choice based on anticipated outcome of the elections. Rational Choice Theory can be evaluative which is the measurement of candidates' performance and non-evaluative which might be voting according to clientalistic tendencies such as ethnic group, religion [14]. Swing voting under Rational Choice Theory may occur especially in developing democracies where variables like ethnicity, parties and candidates campaign strategies, poverty, corruption and analysis of clientalism versus collective public goods determine the pattern of choice of the voters [15]. The theory has three major assumptions which are: all decisions are rational; the democratic political system is consistent and there is a level of uncertainty in the process of choice [16]. The theory clearly explains the events of 2015 General Elections in the sense that voters used their rational choice by voting for an opposition party against the sixteen year ruling PDP due to considerations such as poverty, corruption and provision of collective public goods. The swing voting identified above by Lindberg also occurred where many electorates especially in the Northern part of Nigeria voted for APC because of ethnic and regional attachments more than rational choice in the elections [17]. The second theory which is also related to the above is Clientalism. Clientalism as a theory emerged in the 1970s and 1980s. Clientalism involves complex networks of patron brokerage selectively reaching different strata, sectors and groups and pervading political parties, factions and administrations [18]. Clientalism is a phenomenon that operates against the principles of democratic rule and civil liberty. Clientalism is a theory or a model developed by scholars to interpret the political economy of governance and election through a patron-client relationship [19-22]. Clientalism is a political activity and a strategy which involve vote buying and rewarding of voters and political sponsors for undeserved favour which leads to corruption and abuse of political offices [23]. The theory is simply an explanation of how patron-client relationship and how it emerged in a particular state starting from struggling for power particularly election into a political office [24]. Clientalism is not only a mutual client-patron relationship as sometimes it can be the use of threat or coercion to manipulate political power [25]. In general, it slows democratic rule and good governance as well as undermine democratic rule where some voters elect candidates for some side payments or in return for undue advantage in resource distribution. Basically, Clientalism has five major assumptions which include: the relationship is dyadic; the relationship is asymmetrical; the relationship is personal and enduring; the relationship is reciprocal and the relationship is voluntary (German Institute for Global and Area Studies GIGA. The relationship is illustrated below using a model for clear understanding (Figures 1 and 2). The first diagram indicates a direct relationship between the patrons and their client while the second

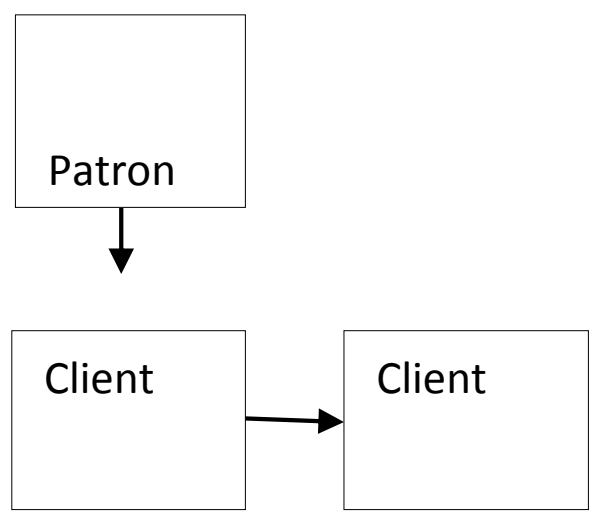

Source: GIGA, 2010

Figure 1: Showing patron-client relationship in clientalism. 


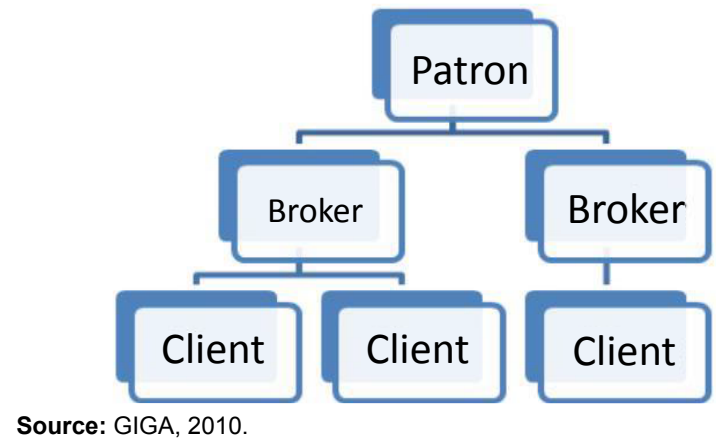

Figure 2: Showing patron-broker-client relationship.

diagram illustrates that, there might be intermediaries sometimes as brokers who prompt for the client and relate with the client on behalf of the patron. Most of African democracies are seen as clientalistic in nature where African leaders tend to distribute personal favours in return for political support, offices and resources are allocated based on kinship and ethnic ties [26-29]. Thus, the theory is applied in explaining this work in the sense that African politics is patrimonialism which is ethnic based and religious in nature and that African politics seems unique in nature [30]. Hence, Nigeria can give a good representation of African politics and its clientalistic nature. Clientalism therefore explains the incidence and nature of the 2015 General Elections and corruption in Nigerian state in the sense that political party financing has been turned into a means of looting public funds and redistributing it among the patrons, brokers and clients in order to secure support and manipulate the elections. The two theories presented above so far disclosed a very sharp and clear understanding of Nigerian election and it would be pertinent to merge them in explaining further the nature and uniqueness of the 2015 General Elections. In the first place, the two theories are contemporaries with both surfacing within the arena of academic realm in the mid $20^{\text {th }}$ century. Secondly, they share similar assumption in terms of identifying the relationship between the voters and the political parties in the case of Rational Choice Theory and Patron-Client relationship in the case of Clientalism which are synonymous. This is because the political parties and patron as well as the voters and the client are equal. The relationship is mutual, beneficial and rational where each of the parties assumes an expected reward from his loyalty to the other parties.

\section{Literature Review}

In this section, various literature involving scholastic views and arguments are going to be reviewed with a view to identify the literature gap and showcase the contribution of the research in the field of knowledge. In this perspective, issues such as political parties, political party financing, political behaviour, corruption, elections and 2015 General Elections are discussed.

\section{Political parties in Nigeria}

Burke opined that a political party is an assembly of men cooperated for promoting of national interest on some common political principles that they all agreed. Political parties serve as the motive force in synchronizing public opinion and as unifying platform that make democracy workable [31]. Similar to the above view, political party is seen as group of individuals bonded in the same policy and principles with special target for achieving such goals through capturing of power [32]. There are two major views on political parties from Liberal and Marxist perspective. The Liberalist sees political parties as the institutions of harmonisation of public opinion which helps the political system. In essence, Liberalist identifies political parties as platforms or machineries for struggle to capture power in a democratic regime. On the other hand, the Marxist views political parties as the tools for power struggles, domination and oppression which will lead to struggles from the masses [33-36]. Political parties performed many functions including uniting and stabilizing political process; struggles for capturing power; linking the government with the people; recruitment of political leaders; setting of values and principles for the society; brokers of ideas; political modernisation especially in developing democracies and performing the role of opposition [3740]. Nigerian political parties are seen from the perspective of African political parties which commonly share unique features. African parties are similar in structure with Western political parties but different in operation. However, the factors that influenced the emergence of parties in Europe and Africa are not the same. In Nigeria, party politics has been the major foundation of political parties. Political parties started in the Fourth Republic (1960-1966) from association and movement to ethnic and regional groups later. During the First and Second Republics (1960-1966 and 1979-1984), the party system is multi-party with many political parties registered. It is only in the Aborted Third Republic that two party system was introduced. Political parties in the Fourth Republic are multi-party system with more than fifty registered parties from 1999 to date [41-44]. However, most of the political parties are not ideologically oriented but rather ethnic based and regional in outlook [45]. Political parties in Nigeria's Fourth Republic are multi-party and have the same characteristics with the previous ones. Historically, political parties in the Fourth Republic emerged from the pressure of demilitarization and transition to democratic rule after prolonged decades of military rule [46]. In the Fourth Republic, initially, three parties were registered: All Peoples Party (APP); Alliance for Democracy (AD) and Peoples Democratic Party (PDP). In practice, the PDP as the ruling party turned the politics into a one party system with a total domination of more than 70 percent of State Governors and Members of National Assembly for straight sixteen years (16) until it was defeated by the opposition All Progressive Congress (APC) for the first time an incumbent was defeated in the history of the country [47-50]. Political parties in Nigeria's Fourth Republic are characterized with the politics of violence, rigging, intra-party conflicts, manipulation of elections result, vote buying, corruption and elections irregularities [51]

\section{Political party financing in Nigeria}

The concept of political party financing has increasingly becomes an issue of great concern for analysts, policy makers and commentators worldwide. It is an avenue for sponsoring campaign activities to capture power but which should be transparent and less corrupt in nature to enable for fair play. The status and transparency of political parties is very important for a sound democratic rule [52]. Citizens are becoming more concern with financing of political parties universally most especially in Nigeria during the 2015 General Elections [33]. The IDEA Handbook of Political Financing examined various rules and regulations in political party financing across continents including sources of campaign finances, donations, contributions limits, maximum spending and other issues related to it. The process of political party financing and elections in Nigeria during the Fourth Republic is seen as perpetuating corruption where politicians especially from the ruling party diverted public funds for buying their ways into offices [53]. Elections campaign in Nigeria is very expensive due to cost of media spending, corruption, political culture, zero sum game, crowd renting and weak political institutions [54]. Money is influential in Nigerian democracy because most of the political activity is impossible without 
it. Money politics is caused in Nigeria because the political parties have the ultimate aim of winning power at all cost to have access to public resources for personal gain. They tend to employ all resources available through private funding towards that purpose which corrupted the process. Money has impacts on politics in Nigeria with implications for democracy especially in developing democracies like that of Nigeria often times resulting as a source of corruption there emerged what is termed "Godfathers" who sponsored anointed candidates in return for favours and resources distribution. There are constitutional and electoral acts which provide rules and regulations for political party financing in Nigeria but the problem is adhering to the provisions and the ability of the electoral body to monitor the process and sanction the offenders. For instance, all issues related to finances of political are covered in Section 225 of the Constitution while reports on finances are covered by section 226. The Sections above empowered the electoral body; Independent National Electoral Commission (INEC) to examine and study all income and expenditures of political parties in the Fourth Republic and punish the offenders. In addition, the 2010 Electoral Act provides some sections for political party financing, maximum limit of campaign spending. Monitoring and auditing of political parties as in Section 88 which provides for offences in relation to finances of political party and their sanctions; Section 89 provides for period to be covered by annual reports of political parties expenditure; Section 90 which set maximum limit for contributions to parties and individuals; Section 92 which provide legal framework for election expenses of political parties and Section 93 which provides for disclosure of donations and expenses of political parties periodically. Most importantly, Section 91 with its subsections provides for limitations on elections expenses for candidates and sanctions for offenders which elaborate the following (Table 1). The sub-section 91 (9,10 and 11) further provides for sanction of fees on the above various elective offices for failure to adhere to the maximum spending limit provided for alternative of charges, imprisonment or both depending on the gravity of the offence. Apart from the above provisions, there is also a constitutional provision for funding of INEC; the electoral body in the conduct of elections in Nigeria in Section 3 (2) of the 2010 Electoral Act which identified that INEC should be funded from consolidated revenue approved by the National Assembly. A whooping sum of N 125 billion ( $\$ 340,863,696.382$ million) was provided by the government for the electoral body (INEC) for the conduct of the 2015 General Elections (Ahar, 2015). Another important issue in political financing in general in developing democracies is the role of international donor agencies. There are evidences of assistance from donor agencies since 1999 in Nigeria for conduct of elections but it was insignificant as the Nigerian Government is financially buoyant to undertake elections expenses roundly. UNDP, USIAD, UKAID, DFID and CIDA provided some millions of Pounds, Dollars and Euros to support elections in Nigeria

\begin{tabular}{|l|l|}
\hline Position & Spending Limit \\
\hline Presidential Candidate & N1 Billion $(\$ 3,183,870.91)$ \\
\hline Governorship Candidate & N200 Million $(\$ 636,774.18)$ \\
\hline Senatorial Candidate & N40 Million $(\$ 127,354.84)$ \\
\hline Member Federal House of Representatives & N20 Million $(\$ 63,677.42)$ \\
\hline State House of Assembly Members & N10 Million $(\$ 31,838.71)$ \\
\hline LG Chairmanship Candidate & N10 Million $(\$ 31,838.71)$ \\
\hline LG Councillorship Elections & N1,000,000 $(\$ 3,183.871)$ \\
\hline
\end{tabular}

Source: Federal Republic of Nigeria, Electoral Act 2010 as Amended (the conversion into USD was made by the researcher).

Table 1: Showing spending limits of candidates according to 2010 Electoral Act. Source: Federal Republic of Nigeria, Electoral Act 2010 as Amended (the conversion into USD was made by the researcher). through training of INEC staff, provision of logistics, empowering of weak groups and civil societies (Bariledum et al. 2016).

\section{Corruption}

The subject matter of corruption in Nigeria is a very interesting academic exercise which is still ongoing as a result of the notorious reputation that the country developed among the comity of nationstates in corrupt practices as well as the nature and dimension of corruption which differ from that of many countries. It is seen as many issues to many scholars. Political corruption is a fraud perpetrated by political class as the so called democracy even in democracies convenes corruption and corrupt practices through electoral process which contradict the expectation of many people who saw democracy as the best. The view above by Ackerman is also advanced by Balboa and Medalla. Corruption in Nigerian context includes the demand of electoral politics and the extensive use of patron-client favouritism. The systemic corruption in Nigeria leads to a particular political culture of money politics and unequal resources distribution. Corruption spread in Nigeria like a wildfire destroying all institutions along the process. The anti-graft agencies were politicized which made corruption to escalate in the country. In addition, corruption is perceived as weak political institutions and organised state crime as well as the use of public treasury for private gain. A study in political corruption in Nigeria identified the endemic nature of clientalism and patrimonialism as the major sustenance of corrupt practices where the elites has unlimited access to national wealth through power control. There are various explanations advanced by scholars on the major causes of corruption in Nigeria including; poverty and poor condition of work, economic bargains and activities of multinational corporations rent and rent seeking, weak political institutions and low human development indicators social and political factors and prolong military rule. Corruption manifested in Nigeria in every aspect of political, cultural and socioeconomic activities in the country. An annual report by Transparency International, an international organisation that analyses corruption and corrupt practices revealed that corruption exists in all countries of the world but the degrees of the incidences differed sharply. Nigeria is one of the most corrupt countries according to Transparency International. Corruption manifested in Nigeria in many perspectives as the indices of Corruption Perception Index provided by Transparency International disclosed that Nigeria from 1996 to date is always falling among the most highly corrupt countries Transparency International. There are more than 300+ established corruption cases in Nigeria from 1999 only to 2013 and there shall be as equal that number from 2013 to 2017 or more than frequency. A report released by African Union indicates that about $n \$ 500$ billion was stolen from Nigeria since political independence. Corruption manifested in all segments of the society in Nigeria from bureaucratic to political, economic and individuals. All institutions of government are found with one corrupt case and scandal or the other [55].

\section{Political culture and elections in Nigeria's fourth republic}

Political culture is the citizens' attitude towards political process, policy making process and policy outcomes and outputs. It involves the attitudes, sentiments and cognitions that inform and govern political behaviour in any society. It is a new term in contemporary political discourse which depicts concept such as national ideology, national ethics, national psychology and fundamental values of the people. Political culture is simply defined as the particular distribution of patterns of orientation toward political objects among the members of a nation. There are many meanings and aspects of culture but political 
culture is specifically related or referred to political ethics, moral values, beliefs and the myths that people live with in their political environment. Nigerian political culture is the reminiscent of historical antecedents from pre-colonial period, colonial and post colonial periods. The pre-colonial geography of Nigeria consisted of larger and smaller states which came into existence as early as $10^{\text {th }}$ century. While some of the states are centralized and administratively organised like Hausa/Fulani kingdom and Yoruba, others are decentralized and smaller in nature. Nigeria has a complex heterogenous culture of Western values imposed on indigenous culture in a diverse multiethnic and multi-religious society. Ethnic identity easily became the political culture of Nigerians during elections. In addition, the political behaviour of Nigeria especially towards elections indicates a behaviour of rigging, manipulation of ethnicity, regionalism and religion. Voters are voting in an election based on the religious, regional and ethnic affiliation of the candidates and not on credibility or performance. As a result of the influence of money politics, massive campaign spending and weak institutions for sanction of legal regime against violation of electoral rules, elections are marred with culture of rigging, vote buying, bribing of electoral officers and security agencies, heavy use of money to bribe all cooperating stakeholders in elections conduct, elections malpractices, intimidation of voters and opposition, use of violence, political thuggery, god fatherism and looting of public treasury by those in political offices to finance their campaign activities [56].

\section{5 general elections in Nigeria}

Election is the most fundamental sustenance of any democratic rule in the world. It is an organised event periodically which involves political office seekers and voters where a peaceful choice of leadership is made. Election is viewed as a legitimizing institution functioning to give elected leaders the wire withal to govern. The 2015 General Elections in Nigeria has been giving much popularity for its uniqueness because it was the first time in the history of the country that an incumbent was defeated by an opposition in a free, fair and what most scholars identified as credible elections [57,58]. The March 28 and April 14 2015 General Elections marked another turn in the history of Nigerian politics as it was the first time that the opposition unseat the incumbent President in a successful election. Of the sixty seven million and four hundred and twenty two thousand and five (67, 422, 005 million) registered voters, only thirty one million and seven hundred and forty six and four hundred and ninety $(31,740,490$ million) were accredited for 2015 Presidential elections. Twenty nine million and four hundred and thirty two and eighty three $(29,432,083$ million) of the votes were casted with $97 \%$ of the votes valid [59,60]. The 2015 General Elections and the outcome were entirely different from the previous elections in Nigeria in many different ways. In the 2015 Presidential elections, 14 (fourteen) political parties contested for the post of Presidency, less votes were cast in 2015 than in 2011 by $25 \%$, the incumbent lost to the opposition by $45 \%$ to $54 \%$, the opposition won more States 21 out of 36 (CPPA, 2015). The outcome of elections revealed that, the results indicated a reverse of trend in the number of seats won in the National Assembly as the APC won most of the seats in the upper chamber with $55.05 \%$ and the lower chamber with $62.5 \%$ and the APC went ahead to form the leadership of both the houses dislodging PDP from its strong hold majority leadership of 16 years rule. One of the distinguishing features of the 2015 General Elections is; it is regarded as the most credible of all the previous elections in the Fourth Republic. There are many writings, reports and observers that took that position, Nigerian Civil Society Situation Room, 2015). Such position is also agreed upon by many of the informants in this research that were consulted during the field work that the 2015 General Elections is the most credible in the Fourth Republic [61]. And this position has been agreed upon by both the ruling and opposition parties after the election. Reasons advanced by the informants interviewed in this work for the credibility of the elections include: role of civil societies; opposition parties; use of smart card readers which curbed rigging drastically; an improved electoral umpire; issue-based campaign; massive use of money; electoral reforms; electoral administration; international observers; social media; fair play; socioeconomic issues; voters determination; wind of change; minimised rigging and decamping from ruling party to opposition [62].

\section{Discussion of Major Findings}

There are evidently various discourses, findings, revelations, analyses and views of scholars, commentators, analysts and various segments of the society on the 2015 General Elections in Nigeria particularly on the amount of money spent, corruption and illegal practices in the process as well as the issue of credibility of the elections. In the first place, it is pertinent to observe that no individual no matter his experience and closeness to government as well as the privilege information he possesses can tell you exactly how much is spent by politicians or how many are bribed or those that are involved in corruption scandals emanating from the 2015 General Elections. The informants that were interviewed in this work gave their best based on what they know. The research complemented with the existing literature to make the discussion of findings. Most of the informants consulted revealed that the election is the most expensive in the history of the country as the estimated cost spent by the then ruling PDP along is approximately billions of dollars or trillions of Naira. This has been corroborated by the recent revelations from the EFCC of the $\$ 2.1$. Billion (N777, 133,624,337, 580.00 billion) arms scandal where the former National Security Adviser's office; Colonel Sambo Dasuki was used to divert the sum earmarked for procurement of arms to fight Boko Haram insurgency for PDP campaign in 2015. The issue is currently under investigation by the anti-graft agency (EFCC). This revealed three issues. First, the campaign money was sourced from the government's treasury directly, secondly there was excessive spending above the maximum financial ceiling set by electoral laws and finally there is massive corruption in the electoral process in Nigeria. The above views obtained from the informants that were interviewed have also been supported by many scholars who studied similar topic before even before the 2015 General Elections using the previous ones conducted and the evidences of the emerging one as all the scholars agreed that the process of political party financing is bedeviled with massive corruption and huge use of public funds for campaign. The spending in the 2015 General Elections in their views is outrageous and undemocratic in whatever perspective. Ironically and unfortunately, the ruling PDP lost the elections and the newly ruling party APC which seems determine to address the issue of corruption being one of the major issues that they campaigned vigorously on started anticorruption movement within a short period of a time, shocking discoveries emerged of the outrageous spending by PDP in the 2015 General Elections and the corruption scandals involved in it. One of such revelations is the Dasukigate scandal where \$2.1 billion (N777, $133,624,337,580.00$ billion) earmarked for procurement of weapons to fight Boko Haram was diverted by PDP for campaign (EFCC, 2017). A Committee of investigation was inaugurated by the new government of APC to investigate the arms scandal. The investigations revealed that, among the beneficiaries of the arms deal who receive the proceeds of the loot are former Nigerian leaders, traditional leaders, religious leaders, former heads of states and indeed, serving and retired officers, 
contractors, very prominent Nigerians. The report recommended for retrieval of money from the indicted fellows and prosecution of others that are involved (EFCC, 2017). Some of the beneficiaries that were publicly revealed and quizzed by EFCC are presented below and the amount involved (Table 2). Apart from the above, some of the investigations that involved religious clerics and traditional rulers as well as former Heads of State were carried out in secrecy off the public domain. Besides, the one that involves contract scandals for the 241 companies was valued at $\mathrm{N} 13,729,342,329.87(\$ 37,716,079.90113)$

\begin{tabular}{|l|l|l|}
\hline S/No. & Person/Group & Amount \\
\hline 1. & PDP Delegates & $\mathrm{N} 10$ billion $(\$ 27,253,336.883)$ \\
\hline 2. & Sagir Bafarawa/Dalhatu Investment & $\mathrm{N} 4,633,000,000(\$ 12,626,470.98)$ \\
\hline 3. & Jabbama Ada Global Nigeria Limited & $\mathrm{N} 400$ million $(\$ 1,089,322.35)$ \\
\hline 4. & R.R. Hospital & $\mathrm{N} 750$ million $(\$ 2,042,479.41)$ \\
\hline 5. & ACACIA Holdings Limited & $\mathrm{N} 1.25$ billion $(\$ 3,404,132.358)$ \\
\hline 6. & Barrister I.M. Bala & $\mathrm{N} 150$ million $(\$ 408,495.883)$ \\
\hline 7. & Malam Ibrahim Shekarau & $\mathrm{N} 900$ million $(\$ 2,450,975.30)$ \\
\hline 8. & Ambassador Ibrahim Yerima Abdullahi & $\mathrm{N} 100$ million $(\$ 272,330.589)$ \\
\hline 9. & Chief Olu Falae & $\mathrm{N} 800$ million $(\$ 2,178,644.71)$ \\
\hline 10. & African Cable TV & $\mathrm{N} 350$ million $(\$ 953,157.060)$ \\
\hline 11. & Nigerian Defense Academy & $\mathrm{N} 159$ million $(\$ 433,005.636)$ \\
\hline 12. & B.B. & $\mathrm{N} 350$ million $(\$ 953,157.060)$ \\
\hline 13. & Abuja Electricity Distribution Company & $\mathrm{N} 125,503,255.11$ \\
million $(\$ 341,783.75344)$
\end{tabular}

Source: Compiled by the researcher from EFCC websites and internet sources (all computation from Naira to Dollar was made by the researcher).

Table 2: Individuals involved in Dasuki Arms Scandal and the amount they have received. while that of the fictitious contract was N2, 219, 188, $609.50(\$ 6,101$, 462.0541) and another E9, 905, $477.00(\mathrm{~N} 4,634,667,716.58)$. The committee also discovered that the National Security Adviser instructed the Central Bank of Nigeria to transfer a total sum of $\$ 132,050,486.97$ (N48, 049, 967, 022. 13) and $E 9,905,473.5(4,631,519,167.42)$ to the account of Societe D'equipmente Internationaux in West Africa, the UK, and the US with no documentation (EFCC, 2017). It is believed that the money diverted from the arms scandal was also used to bribe the INEC staff; the electoral body and other stakeholders related to elections conduct. A report indicated that the EFCC declares that it is going to investigate about 200 of its staff in collaboration with alleged collection of bribe during the 2015 elections. They were queried by INEC and the case was handed over to EFCC. A panel was set under the leadership of the National Commissioner Baba Shettima to investigate the allegations. About N23.29 billion $(\$ 63,822,813.191)$ was allegedly disbursed to INEC officials by the then administration of Goodluck Jonathan. The money was according to investigators released by the former Minister of Petroleum Mrs. Diezani Allison Maduekwe (EFCC 2017). In another report, the INEC confirmed that 202 of its staff were indicted by EFCC who were accused of benefitting from N23 billion bribery allegedly facilitated by the former Minister of Petroleum. The INEC staffs that were indicted were based in 14 states of the country. Some of the affected states are Rivers, Akwa Ibom, Delta, Gombe, Lagos, Kano, Enugu, Anambra, Adamawa, Niger, Jigawa, Zamfara, Edo, Ogun, Osun, Borno, Taraba, FCT Abuja, and other states. The report further revealed that 25 staff were already found guilty in Rivers and were punished accordingly. In addition, the affected staff in the areas where their investigation was not conclusive were redeployed into other states from their former stations (INEC, 2017). The above information from the informants, scholars and EFCC disclosed that the maximum spending limit was violated extremely and massive corruption took place in the process of election. A Report by USAID/ UKAID indicated that both the APC and PDP used public funds during campaign and they also spent above limit as well as also involvement in bribery and corruption scandal. The Report is summarised below (Table 3). The above report also added that, money and administrative resources played an enhanced role in the 2015 Presidential Election. The election appears to have been the most costly and keenly contested since the return to civil rule in 1999. The expenditure ceiling of $\mathrm{N} 1$ billion was largely ignored by the candidates whilst administrative resources were deployed by the two major contenders. Public financial resources were deployed to the election by the two political parties and candidates. The link between the run down finances of states and FGN, the inability to pay workers salaries at the state level and the 2015 elections was very clear. The context of the coming together of the opposition to form the APC which squared up with the PDP candidate provided a near level playing field in terms of access to resources for the candidates [63]. However, surprisingly, while PDP is the highest bidder or spent much above the limit and comparatively higher than that of APC, the PDP lost woefully in the elections. But, the success of APC is not also without financial as many of the informants believed

\begin{tabular}{|l|c|c|}
\hline Campaign Expenses & $\begin{array}{c}\text { PDP Presidential } \\
\text { Candidate }\end{array}$ & $\begin{array}{c}\text { APC Presidential } \\
\text { candidate }\end{array}$ \\
\hline Campaigns and Rallies & $1,280,374,870.00$ & $671,062,200.00$ \\
\hline Expenses on Billboards & $473,160,000.00$ & $190,, 380,000.00$ \\
\hline Electronic Media Campaign & $532,100,000.00$ & $410,050,000.00$ \\
\hline Electronic Media advert & $3,988,822,125.00$ & $1,064,706,805.00$ \\
\hline Print Media Campaign & $2,475,228,301.00$ & $579,647,687.00$ \\
\hline Total & $8,749,685,296.00$ & $2,915,846,737.00$ \\
\hline
\end{tabular}

Table 3: Media spending of two major political parties in the 2015 general elections: APC and PDP. 
that Muhammadu Buhari of APC won because he got cash backing from former PDP members that lately defected to APC. He had been contesting three times in 2003, 2007 and 2011 loosing serially. Money must have played an influential role in his success. But, still, APC spent less and that prompted many scholars to declare the elections credible and fair.

\section{Conclusion and Recommendation}

\section{Conclusion}

In conclusion, the study discovered that elections in Nigeria are used as sources of a cyclical corruption where the ruling elites looted directly from the public treasury and bribe all those involved in the electoral process to have their way into power. Despite the huge spending amounting to billions of dollars and trillions of naira, the ruling PDP lost because of the worsening situation in the country economically and politically as well as security wise. Thus, the election is adjudged the most credible in the Fourth Republic because it was the first time an incumbent was defeated and the electoral process was more transparent and improved which drastically minimised rigging.

\section{Recommendation}

The study recommends the following in order to have a transparent and improved election in the future:

1. The use of electronic smart card readers in accreditation of voters and elections as introduced by INEC should be made into a law and collation of elections results should also be made electronically;

2. The maximum financial spending set for all elective offices should be reviewed upwards to meet the reality of current inflationary trend and the political culture of money politics in Nigeria;

3. INEC should be empowered to introduced more strict rules on monitoring of sources of campaign, spending and violation of rules for severe sanction empowered by law;

4. The anti-graft agency (EFCC) should be incorporated in elections conduct particularly in financial monitoring and screening of candidates and

5. Finally, all those caught in the act of bribery and corruption scandal in the 2015 General Elections should be punished severely and the entire amount should be retrieved from them to deter others in future.

\section{References}

1. Isma'ila Y, Othman Z (2015) Challenges of Electoral Processes in Nigeria's Quest for Democratic Governance in the Fourth Republic. Research on Humanities and Social Sciences.

2. Ayanda AA, Odunayo BJ (2015) Comparative Study of Presidential Elections in Nigeria Global. Journal of Human Social Sciences: F Political Science.

3. Chukwudi OR (2015) Democratic Consolidation in Nigeria: Progress and Challenges. Arabian Journal of Business and Management Review. Civil Society Situation Room Nigeria.

4. Omilusi MO (2015) An Assessment of Political Parties and Democratic Consolidation In Nigeria's Fourth Republic European, Journal of Research in Social Sciences.

5. Londono JF, Zovatto G (2014) Regional Studies on Political Finance: Regulatory Framework and Political Realities Latin America.

6. Ukase PI (2015) Political Parties and Election /Campaign Financing in Nigeria: Interrogating the General Elections.
7. Ayoade JAA (2008) Godfather Politics in Nigeria in Adetula VOA Money and Politics in Nigeria Abuja: DFID.

8. Adetula VOA (2008) Money and Politics in Nigeria: an Overview in Adetula VOA Money and Politics in Nigeria Abuja: DFID.

9. Adeyi EM (2008) Funding of Political Parties and Candidates in Nigeria: Analysis of The Past and Present in Adetula VOA. Money and Politics in Nigeria Abuja: DFID.

10. Nkechi A (2014) Innocent EO Political Financing in Africa: A Comparative Study for Kenya and Nigeria: Proposal for Reform, Mediterranean Journal of Social Sciences MCSER.

11. Ackerman SR (1999) Political Corruption and Democracy US: Yale School of Law.

12. Ahar UC (2015) Historical Dialectics of Presidential Election: Implication for Sustainable Democracy in Nigeria. European Scientific Journal.

13. Ake C (1996) Democracy and Development in Africa Washington: Brookings.

14. Almond G, Powell GB, Strom K, Dalton RJ (2005) Comparative Politics Today: A World View New Delhi: Pearson Education Inc.

15. Almond G, Verba S (1963) The Civic Culture: Political Attitudes and Democracy in Five Nations Princeton: Princeton University Press.

16. Amundsen I (1997) Political Corruption: An Introduction to the Issues Chris Michelsen Institute: Development Studies and Human Rights

17. Antunnes R (2010) Theoretical Models of Voting Behaviour Escola Superior De Educacao- Instituto Politecnico de Coimbra.

18. Appadorai A (2004) The Substances of Politics New Delhi: Oxford University Press.

19. Arrows K (1986) Rationality of Self and others in Economic System. The Journal of Business.

20. Babawale T (2006) Nigeria in The Crises of Governance and Development: $A$ Retrospective and Prospective Analysis of Selected Issues and Events: The Political Economy of Development Governance and Globalisation Vol I Lagos: Political and Administrative Resource Centre (PARC).

21. Bailey J (2006) Corruption and Democratic Governability in Latin America: Issues of Types Arenas Perceptions and Linkages Prepared for the Meeting of the Latin American Studies Association San Juan Puerto Rico.

22. Bakare AS (2011) The Crowding-out Effects of Corruption in Nigeria: An Empirical Study. Journal of Business Management and Economics August.

23. Balboa J, Medalla EM (2006) Anti-Corruption and Governance: The Philippine Experience Philippines Institute for Development Studies APEC Study Centre Network.

24. Bariledum K, Godpower NB, Tambari NS (2016) Foreign Democratic Assistance to Nigeria The Nexus Between Strategy and Elections Results. Global Journal of Political Science and Administration.

25. Creswell JW (2014) Educational Research: Planning Conducting and Evaluating. Quantitative and Qualitative Research Edinburgh: Pearson Inc.

26. Dahl R (2000) A Framework of Political Analysis California: Oxford Publishers

27. Daramont CA (2010) The Entrenchment of Clientalistic Practices: Methodological and Conceptual Issues of Transferability in European. Journal of Inter disciplinary Studies.

28. Dike V (2002) Democracy and Political Life in Nigeria Zaria: Ahmadu Bello University Press.

29. Doublet MYM (2010) Fighting Corruption: Political Funding GRECO's Third Evaluation Round

30. Downs A (1957) An Economic Theory of Democracy New York: Harper Collins Publishers, conomic and Financial Crimes Commission Electoral.

31. Hassan MB and Lamidi KO (2001) The Ruling Party and Reaction to Opposition Parties in Nigerian Politics: Matters Arising.

32. Heywood A (2000) Politics New York: Palgrave Publishers

33. IDEA (2015) Funding of Political Parties and Election Campaign: A Handbook Of Political Finance, Stockholm: International IDEA.

34. Ikubaje J (2014) Nigeria Anti-Corruption Initiatives and the Constitution Centre for Democracy and Development in Lagos. 
Citation: Sule B, Azizuddin M, Sani M, Mat B (2017) Political Party Financing and Corruption in Nigeria's Fourth Republic: The Case of 2015 General Elections. Arts Social Sci J 8: 298. doi: 10.4172/2151-6200.1000298

Page 8 of 8

35. International Republic Institute Nigeria National Elections (2015).

36. Isaksson AS and Bigsten A (2013) Clientalism and Ethnic Division in JEL Classification.

37. Johari JC (2011) Comparative Politics New Delhi: Sterling Publishers.

38. Kapur AC (2009) Principles of Political Science New Delhi: S Chand.

39. Knuckles JA (2006) A Study of Corruption's Causes in Botswana and Nigeria.

40. Kura BY (2014) Clientale Democracy: Political Party Funding and Candidate Selection in Nigeria. African Journal of Political Science and International Relations.

41. Kurfi A (1983) The Nigerian General Elections: 1959 And 1979 and The Aftermath Ibadan: Macmillan.

42. Lawal SM (2015) An Appraisal of Corruption in the Nigeria Electoral System European Scientific Journal.

43. Lindberg SI and Morrison M (2008) Are African Voters Really Ethnic or Clientalistic? Survey Evidence from Ghana Political Science Quarterly.

44. Lindberg SI, Weghorst KR (2010) Are Swing Voters Instruments of Democracy or Farmers of Clientalism Evidence from Ghana. The QOG Institute Quality of Government.

45. Lucian PW (1962) Politics Personality and Nation Buildings New Delhi: Pearson Education Inc.

46. Lucian PW, Verba S (1965) Political Culture and Political Developmen Princeton: Princeton University Press.

47. Magstadt TM (2006) Understanding Politics: Ideas Institutions and Issues London: Thompson Learning Holborn House.

48. Mauro P (1998) Corruption: Causes Consequences and Agenda for Research Journal of Finance and Development.

49. Mbaku JM (2010) Bureaucratic and Political Corruption in Africa: The Public Choice Perspective Malabar: Kreiger Publishing.

50. Mohammed U (2013) Corruption in Nigeria: A Challenge to Sustainable Development In the Fourth Republic, European Scientific Journal February.

51. Morse JG, Mazzuca S, Nichter S (2010) Varieties of Clientalism: Machine
Politics during Elections Centre on Democracy Development and the Rule of Law.

52. Mundt RJ and Aborishade O (2005) Politics in Nigeria in Comparative Politics Today: A World View New Delhi: Pearson Education Inc.

53. Obazee G (2014) The Effects of Corruption on the Inflow of Foreign Direct Investment into Ten Sub-Saharan African Countries: Using Ghana and Nigeria as Discussion Points $\mathrm{PhD}$ Thesis submitted to the Faculty of Wilmington University.

54. Ogundiya IS (2009) Political Corruption in Nigeria: Theoretical Perspectives and Some Explanations The Anthropologists.

55. Olayode KA (2015) Ethno-Regional Cleavages and Voting Behaviour in theGeneral Elections: Issues and Challenges for Democratisation, Nation Building National Conference on Elections in Nigeria.

56. Olorunmola A (2016) Cost of Politics in Nigeria Westminster Foundation for Democracy.

57. Omilusi M, Adu AOP (2016) Party Politics and Democratic Governance in Nigeria: Historical Perspective, International Journal of Multidisciplinary Academic Research Organisation for Economic Countries and Development (OECD) Publication.

58. Roniger L (2004) Political Clientalism Democracy and Market Economy in Comparative Politics.

59. Saka L, Ifejika SI (2001) An Assessment of the Historical Development of Political Parties in Nigeria. In: Mohammed H (ed.) The Patterns and Dynamics of Party Politics in Nigeria's Fourth Republic Kano: Hallmark Publishing Nigeria LTD.

60. Salih MJ (2003) African Political Parties USA: Pluto Press.

61. Shehu AY (2006) Combating Corruption in Nigeria: Bliss or Bluster? Journal of Financial Crime.

62. Stokes SC (2013) Clientalism in Oxford Handbooks Online The Centre for Public Policy Alternatives (CPPA) Presidential Election Outcome: Analyses and Implications, Transparency International Report.

63. USAID, UKAID (2015) Still Above The Ceiling: A Report on Campaign Finance and Use of State Administrative Resources in the Presidential Election, Centre for Social Justice. 